\title{
Skin Response Evaluator
}

National Cancer Institute

\section{Source}

National Cancer Institute. Skin Response Evaluator. NCI Thesaurus. Code C117691.

A person who determines the significance of a skin response assessment. 